\title{
PEMANFAATAN LUMPUR WASTEWATER TREATMENT PLANT DAN ABU BOILER INDUSTRI REFINERY DAN BIODIESEL MINYAK KELAPA SAWIT DENGAN SISTEM IN VESSEL COMPOSTING \\ USE OF WASTEWATER TREATMENT PLANT AND BOILER ASH \\ PALM OIL REFINERY AND BIODIESEL INDUSTRY \\ WITH IN VESSEL COMPOSTING SYSTEM
}

\author{
Elsa Rahmadayani ${ }^{1}$, Andy Mizwar ${ }^{2}$, Riza Mittahul Khair ${ }^{2}$ \\ ${ }^{1}$ Program Studi Teknik Lingkungan Fakultas Teknik UNLAM, Jl. A. Yani Km. 36 Banjarbaru \\ ${ }^{2}$ Dosen Pembimbing dan Staf Pengajar Fakultas Teknik UNLAM, Jl. A. Yani Km. 36 Banjarbaru \\ E-mail: elsarahmadayani@gmail.com
}

\begin{abstract}
ABSTRAK
Industri refinery dan biodiesel minyak kelapa sawit menghasilkan limbah yang masih tergolong sebagai limbah B3, yaitu lumpur WWTP dan abu boiler. Pengelolaan limbah B3 menggunakan pihak ketiga relatif mahal, untuk itu dilakukan penelitian in vessel composting sebagai alternatif pengelolaan limbah B3 industri refinery dan biodiesel minyak kelapa sawit. Penelitian ini bertujuan untuk menganalisis kualitas kompos yang dihasilkan dari lumpur WWTP dan abu boiler dari industri refinery dan biodiesel minyak kelapa sawit, menganalisis kondisi optimum composting lumpur WWTP dan abu boiler dari industri refinery dan biodiesel minyak kelapa sawit berdasarkan komposisi bahan composting terhadap kualitas kompos, dan menganalisis perbandingan efisiensi biaya pengelolaan lumpur WWTP dan abu boiler dengan in vessel composting dan dengan menggunakan pihak ketiga. Lumpur WWTP dan abu boiler yang digunakan berasal dari industri refinery dan biodiesel minyak kelapa sawit di Desa Tarjun, Kotabaru, Kalimantan Selatan. Hasil penelitian menunjukkan bahwa kualitas kompos yang dihasilkan dari lumpur WWTP dan abu boiler industri refinery dan biodiesel minyak kelapa sawit sesuai dengan SNI 19-7030-2004 dan Permentan No. 70 Tahun 2011, dengan kandungan C-Organik sebesar 16,16\%, kandungan N-Total sebesar 0,41, nilai rasio $\mathrm{C} / \mathrm{N}$ sebesar 40,51 dan warna kompos kehitaman. Kondisi optimum composting berdasarkan variasi komposisi bahan composting terhadap kualitas kompos adalah R-5, $50 \%$ lumpur WWTP + 50\% sampah organik, dengan kandungan C-Organik rata-rata sebesar $17,157 \%$ dan kandungan N-Total rata-rata sebesar 0,313\%. Sedangkan untuk efisiensi biaya pengelolaan, biaya pengelolaan dengan in vessel composting lebih efisien dibandingkan dengan menggunakan pihak ketiga dengan efisiensi sebesar 45,59\%.
\end{abstract}

Kata Kunci: lumpur WWTP, abu boiler, sampah organik, in vessel composting, industri refinery dan biodiesel minyak kelapa sawit

\section{ABSTRACT}

The palm oil refinery and biodiesel industry produces B3 waste, i.e. WWTP sludge and boiler ash. The management of $B 3$ waste using third person is relatively expensive, therefore in vessel composting research is done as an alternative to manage B3 waste of palm oil refinery and biodiesel industry. The aim of this research are to analyze the compost quality of WWTP sludge and boiler ash from palm oil refinery and biodiesel industry, analyze optimum condition composting of 
WWTP sludge and boiler ash from palm oil refinery and biodiesel industry based on variation of composting material composition against quality of compost, and analyze cost efficiency comparisons management of WWTP sludge and boiler ash with in vessel composting and by using third parties. WWTP sludge and boiler ash taken from palm oil refinery and biodiesel industry in Tarjun Village, Kotabaru, South Borneo. The results showed that the quality of compost produced by using WWTP sludge and boiler ash of palm oil refinery and biodiesel industry is appropriate with SNI 19-7030-2004 and Permentan No. 70 Tahun 2011, with C-Organic content of 16.16\%, NTotal content of $0.41, C / N$ ratio of 40.51 and blackish compost color. The optimum condition of composting based on composting material composition is $R-5,50 \%$ WWTP sludge $+50 \%$ organic waste, with an average C-Organic content of $17.157 \%$ and an average $N$-Total content of $0.313 \%$. And for management cost efficiency, the cost of management with in vessel composting is more efficient than using third person with efficiency of $45.59 \%$.

Keywords: WWTP sludge, boiler ash, organic waste, in vessel composting, palm oil refinery dan biodiesel industry

\section{PENDAHULUAN}

Industri refinery minyak kelapa sawit merupakan industri yang mengolah minyak mentah kelapa sawit (Crude Palm Oil) menjadi minyak murni mencakup tahap pembuangan zat sisa, warna, serta rasa dengan menggunakan proses refening, bleaching, dan deodorization (RBD). Komponen cair (olein) dari minyak kelapa sawit digunakan secara luas sebagai minyak goreng. Sedangkan biodiesel berbasis minyak sawit merupakan salah satu sumber energi terbarukan yang bersumber dari minyak sawit. Penggunaan minyak sawit sebagai sumber biodiesel oleh Pertamina pada awalnya dimulai dengan pencampuran $1 \%$ dengan solar, produk pencampuran biodiesel dengan solar yang dihasilkan Pertamina dikenal dengan sebutan biosolar. Peningkatan konsumsi produk biosolar semakin meningkatkan pemanfaatan biodiesel seiring dengan peraturan pemerintah mengenai mandat penggunaan bahan bakar nabati (BBN) melalui Peraturan Kementerian (Permen) ESDM No 30 Tahun 2008, Permen ESDM No 25 Tahun 2013, dan Permen ESDM No 20 Tahun 2014 (Sembiring, dkk. 2015).

Industri refinery dan biodiesel minyak kelapa sawit menghasilkan beberapa limbah B3 yang sulit di tangani, salah satunya adalah limbah lumpur/sludge wastewater treatment plant (WWTP). Limbah ini termasuk kedalam jenis limbah B3 sumber tidak spesifik yang tercantum dalam peraturan pemerintah nomor 101 tahun 2014, karena kandungan logam berat yang ada pada limbah padat ini sangat berbahaya bagi manusia dan lingkungan (Henggar dan Sugesti, 2009). Selain lumpur WWTP, abu boiler yang dihasilkan selama proses pemanasan juga termasuk kedalam jenis limbah B3 dari sumber spesifik khusus yang tercantum dalam peraturan pemerintah nomor 101 tahun 2014, karena bila abu ditimbun akan menghasilkan gas metana $\left(\mathrm{CH}_{4}\right)$ yang dapat terbakar dengan sendirinya dan berbahaya untuk kesehatan khususnya pada sistem pernafasan dan kulit (Lasryza dan Sawitri, 2012).

Pada umumnya pelaku usaha menyerahkan pengolahan kedua limbah B3 tersebut kepada pihak ketiga. Akan tetapi biaya pengolahan limbah B3 ini cukup tinggi, yaitu Rp 250.000,- per ton, selain itu jumlah timbulan kedua limbah B3 ini cukup besar. Timbulan limbah lumpur WWTP sekitar 1520 ton per hari, sedangkan timbulan abu boiler sekitar 45 ton per hari (Tim EHFS PT SMART Tbk, 
2016). Oleh karenanya untuk mengolah kedua limbah B3 tersebut perlu penanganan yang tepat, efisien dan tidak mendatangkan pencemaran lingkungan kedepannya.

Penelitian ini bertujuan untuk menganalisis kondisi optimum composting lumpur WWTP dan abu boiler dari industri refinery dan biodiesel minyak kelapa sawit, menganalisis kualitas kompos yang dihasilkan dari lumpur WWTP dan abu boiler dari industri refinery dan biodiesel minyak kelapa sawit; dan menganalisis efisiensi biaya pengelolaan lumpur WWTP dan abu boiler dari industri refinery dan biodiesel minyak kelapa sawit dengan in vessel composting dibandingkan dengan menggunakan jasa pihak ketiga.

\section{Metode Penelitian}

\subsection{Lokasi dan Waktu Penelitian}

Penelitian dilakukan skala laboratorium di Laboratorium Teknik Lingkungan, Fakultas Teknik, UNLAM Banjarbaru pada tanggal 01 Mei hingga 04 Juni 2017 (selama 35 hari).

\subsection{Alat dan Bahan Penelitian}

Alat yang digunakan pada penelitian ini yaitu komposter dengan sistem in vessel composting (desain komposter disajikan pada Gambar 1) dan soil tester untuk pengukuran suhu, kadar air, dan pH setiap harinya. Bahan yang digunakan pada penelitian ini yaitu lumpur WWTP, abu boiler, dan sampah organik berupa sampah taman, serbuk gergaji, dan serpihan kayu kecil.

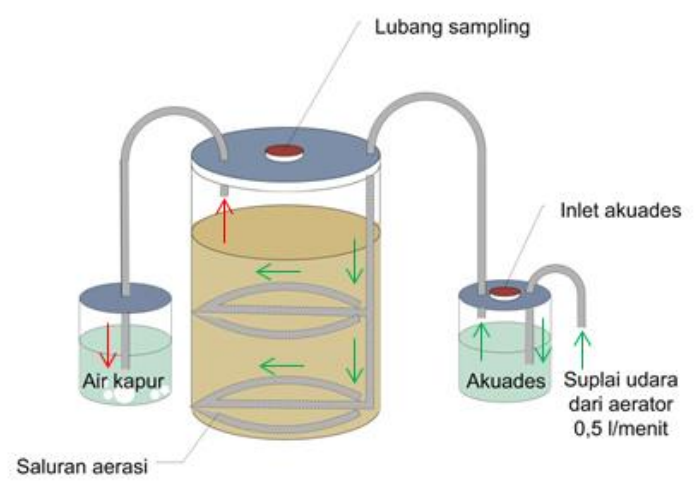

Gambar 1. Desain komposter

Sumber: Mizwar dan Trihadiningrum, 2014.

\subsection{Rancangan Penelitian}

Penelitian ini dilakukan dengan memvariasi komposisi bahan composting untuk mendapatkan komposisi dengan kualitas kompos terbaik sesuai SNI 19-7030-2004 tentang spesifikasi kompos dari sampah organik domestik dan Permentan No. 70 Tahun 2011 tentang pupuk organik, pupuk hayati, dan pembenah tanah. Variasi komposisi bahan composting disajikan pda Tabel 1.

Proses composting pada penelitian ini menggunakan metode aerob dengan sistem in vessel composting. Sistem in vessel composting merupakan proses composting yang berada di sebuah kontainer yang tertutup dengan sirkulasi udara melalui selang yang dilubangi. Udara yang digunakan berasal dari penguapan air (moisture aeration) yang dialirkan dengan kecepatan 0,5 L/menit selama 24 jam (Sari, dkk, 2015). Moisture aeration menyebabkan uap air yang terlepas digantikan oleh uap air yang masuk bersamaan dengan udara yang dialirkan sehingga moisture 
aeration tidak hanya mendukung ketersediaan oksigen tetapi juga membuat kadar air pada proses composting terjaga pada kisaran optimum (50-60\%) (Sari, dkk, 2015).

Tabel 1. Variasi Komposisi Bahan Composting

\begin{tabular}{|c|c|c|c|c|}
\hline \multirow[b]{2}{*}{$\begin{array}{c}\text { Kode } \\
\text { Reaktor }\end{array}$} & \multicolumn{3}{|c|}{ Komposisi } & \multirow[b]{2}{*}{$\begin{array}{c}\text { Rasio } \\
\mathrm{C} / \mathrm{N}\end{array}$} \\
\hline & $\begin{array}{l}\text { Lumpur } \\
\text { WWTP }\end{array}$ & $\begin{array}{c}\text { Abu } \\
\text { Boiler }\end{array}$ & $\begin{array}{l}\text { Sampah } \\
\text { organik }\end{array}$ & \\
\hline $\mathrm{R} 1$ & $50 \%$ & $50 \%$ & $0 \%$ & 3,38 \\
\hline $\mathrm{R} 2$ & $50 \%$ & $35 \%$ & $15 \%$ & 11,75 \\
\hline R3 & $50 \%$ & $25 \%$ & $25 \%$ & 17,33 \\
\hline $\mathrm{R} 4$ & $50 \%$ & $15 \%$ & $35 \%$ & 22,91 \\
\hline R5 & $50 \%$ & $0 \%$ & $50 \%$ & 31,28 \\
\hline R6 & $100 \%$ & $0 \%$ & $0 \%$ & 5,03 \\
\hline
\end{tabular}

Bioaktivator EM-4 yang ditambahkan sebanyak 0,7\% dari total berat bahan composting (Priyambada, 2015). Lama composting pada penelitian ini adalah 35 hari dengan dua kali pengulangan (duplo). Setiap 7 hari sekali dilakukan penganginan bahan kompos dan pengambilan sampel uji. Parameter yang dianalisis pada setiap pengambilan sampel meliputi C-Organik, N-Total, rasio $\mathrm{C} / \mathrm{N}$, pH dan kadar air, hanya suhu yang diukur setiap hari. C-Organik, N-Total, dan rasio $\mathrm{C} / \mathrm{N}$ merupakan parameter penentuan kualitas kompos, sedangkan suhu, kadar air, dan $\mathrm{pH}$ diukur sebagai kondisi composting. Kompos dinyatakan telah matang jika besar rasio $\mathrm{C} / \mathrm{N}$ mencapai atau mendekati angka 10:1 (Setyorini, dkk, 2009). Sedangkan uji kualitas kompos yang dihasilkan berdasarkan SNI 19-7030-2004 tentang spesifikasi kompos dari sampah organik domestik dan Permentan No. 70 Tahun 2011 tentang pupuk organik, pupuk hayati, dan pembenah tanah.

\subsection{Cara Analisis Data}

Analisis yang dilakukan terbagi menjadi dua cara, yaitu secara deskriptif dan statistik. Analisis deskriptif yang digunakan untuk mengetahui adanya perbedaan kualitas kompos yang dihasilkan dari setiap perlakuan dan untuk mendapatkan komposisi kompos dengan kualitas terbaik. Setiap data kualitas kompos, yakni C-Organik, N-Total, dan rasio C/N, dijelaskan satu per satu berdasarkan proses composting yang terjadi, termasuk proses kimia dan biologis yang melibatkan mikroorganisme. Kemudian dibandingkan dengan SNI 197030-2004 tentang spesifikasi kompos dari sampah organik domestik dan Permentan No. 70 Tahun 2011 tentang pupuk organik, pupuk hayati, dan pembenah tanah. Analisis statistik digunakan untuk menentukan kondisi optimum composting. Secara statistik data dianalisis menggunakan metode One-Way ANOVA (Analysis of variance). Alat uji ini untuk menguji apakah dua populasi atau lebih yang independen, memiliki rata-rata yang dianggap sama atau tidak sama (Asriani, 2009). Kemudian dilakukan uji Duncan's Multiple Range Test (DMRT) taraf 5\% jika terdapat perlakuan yang berpengaruh nyata. Uji DMRT digunakan untuk mengetahui jenis terbaik berdasarkan rangkingnya. Sementara untuk efisiensi biaya pengelolaan limbah WWTP dan abu boiler industri refinery dan biodiesel minyak kelapa sawit dianalisis dengan menggunakan analisis komparasi. Analisis ini membandingkan total biaya yang dikeluarkan untuk composting dengan total biaya yang harus dikeluarkan untuk mengolah limbah B3 menggunakan jasa pihak ketiga, dengan tujuan untuk mengetahui tingkat efisiensi pemanfaatan lumpur WWTP dan abu boiler menjadi kompos. 


\section{HASIL DAN PEMBAHASAN}

\subsection{Kualitas Kompos}

Kompos dengan kualitas yang baik dapat dilihat melalui fisik dan kimia kompos. Secara fisik kompos matang ditandai dengan perubahan warna, ukuran partikel dan bau. Berdasarkan SNI 197030-2004 kompos dinyatakan matang jika berwarna kehitaman, berukuran $25 \mathrm{~mm}$ dan berbau tanah. Penampakan kompos setelah 5 minggu proses composting disajikan pada Gambar 2.

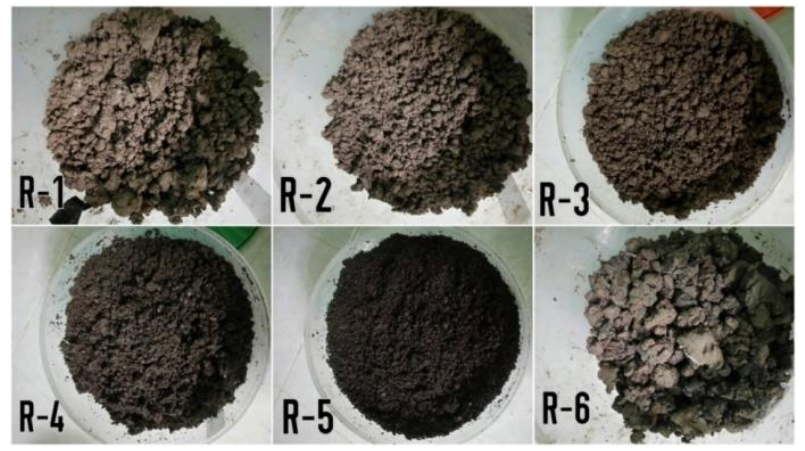

Gambar 2. Penampakan Kompos Hasil Composting

Hasil pengamatan warna dari penampakan kompos yang terlihat pada Gambar 2 menunjukkan bahwa secara visual reaktor yang memiliki kompos dengan warna kehitaman dan ukuran partikel yang lebih kecil adalah R-4 dan R-5. Akan tetapi R-5 memiliki warna yang paling hitam dan ukuran partikel yang paling kecil dibandingkan reaktor-reaktor lainnya. R-5 terdiri dari 50\% lumpur dan 50\% sampah organik. Ini menunjukkan bahwa semakin banyak komposisi sampah organik, semakin hitam warna kompos. Hal ini disebabkan adanya campuran sampah taman dan serbuk gergaji yang tersusun oleh senyawa organik sederhana yang dapat dengan mudah dan cepat didekomposisi mikroorganisme alami yang ada pada bahan composting tersebut (Nur, dkk, 2016).

Perubahan warna kompos menandakan mikroorganisme berfungsi dengan baik untuk mendekomposisi bahan organik. Warna kompos R-1, R-2 dan R-3 sampai akhir pengamatan belum mencapai warna kompos yang baik menurut SNI 19-7030-2004. Ini disebabkan karena reaktorreaktor tersebut banyak mengandung abu boiler yang memiliki logam berat relatif tinggi. Logam berat dalam jumlah dan konsentrasi tinggi dapat menyebabkan mikroorganisme tertekan/ stress (Taberima, 2004), sehingga bakteri tidak mampu mendekomposisi dengan baik. Sedangkan pada R6 yang terdiri dari 100\% lumpur, perubahan warna dan ukuran partikel masih tidak begitu signifikan. Ini disebabkan padatnya bahan composting sehingga oksigen tidak terdistribusi secara baik yang mengakibatkan sedikitnya bakteri yang dapat hidup dan mendekomposisi bahan composting.

Secara kimia kualitas kompos dinyatakan baik jika memenuhi SNI 19-7030-2004 dan/ atau Permentan Nomor 70 Tahun 2011, meliputi parameter C-Organik, N-Total, dan Rasio C/N. Perbandingan hasil analisis kualitas unsur hara pada kompos dengan SNI 19-7030-2004 dan Permentan Nomor 70 Tahun 2011 disajikan pada Tabel 2. 
Tabel 2. Perbandingan Hasil Analisis Kualitas Unsur Hara pada Kompos dengan SNI 19-7030-2004 dan Permentan Nomor 70 Tahun 2011

\begin{tabular}{|c|c|c|c|c|c|c|}
\hline $\begin{array}{c}\text { Minggu } \\
\text { ke- }\end{array}$ & $\begin{array}{c}\text { Kode } \\
\text { Sampel }\end{array}$ & $\begin{array}{l}\text { Kadar } \\
\text { Air }\end{array}$ & $\mathrm{pH}$ & $\begin{array}{c}\mathrm{C}- \\
\text { Organik } \\
\end{array}$ & N-Total & $\begin{array}{l}\text { Rasio } \\
\mathrm{C} / \mathrm{N}\end{array}$ \\
\hline 0 & $\mathrm{R} 1$ & $27,37^{1}$ & $7,88^{2}$ & 8,96 & 0,08 & 112,00 \\
\hline 1 & $\mathrm{R} 1$ & $29,70^{1}$ & $7,93^{2}$ & 1,15 & 0,20 & 5,75 \\
\hline 2 & $\mathrm{R} 1$ & $32,13^{1}$ & $7,26^{1,2}$ & 5,39 & 0,12 & 44,92 \\
\hline 3 & $\mathrm{R} 1$ & $29,26^{1}$ & $7,78^{2}$ & 5,99 & 0,16 & 37,44 \\
\hline 4 & $\mathrm{R} 1$ & $26,24^{1}$ & $7,76^{2}$ & 8,51 & 0,13 & 65,46 \\
\hline 5 & $\mathrm{R} 1$ & $32,07^{1}$ & $7,93^{2}$ & 2,72 & 0,15 & $18,13^{1,2}$ \\
\hline $\begin{array}{c}\text { Minggu } \\
\text { ke- }\end{array}$ & $\begin{array}{c}\text { Kode } \\
\text { Sampel }\end{array}$ & $\begin{array}{l}\text { Kadar } \\
\text { Air }\end{array}$ & $\mathrm{pH}$ & $\begin{array}{c}\mathrm{C}- \\
\text { Organik } \\
\end{array}$ & N-Total & $\begin{array}{c}\text { Rasio } \\
\mathrm{C} / \mathrm{N}\end{array}$ \\
\hline 0 & $\mathrm{R} 2$ & $25,53^{1}$ & $7,70^{2}$ & 9,65 & 0,08 & 120,63 \\
\hline 1 & $\mathrm{R} 2$ & $25,29^{1}$ & $7,76^{2}$ & $10,35^{1}$ & 0,16 & 64,69 \\
\hline 2 & $\mathrm{R} 2$ & $32,49^{1}$ & $7,49^{1,2}$ & 9,75 & 0,20 & 48,75 \\
\hline 3 & $\mathrm{R} 2$ & $33,62^{1}$ & $7,34^{1,2}$ & $9,87^{1}$ & 0,18 & 54,83 \\
\hline 4 & $\mathrm{R} 2$ & $32,23^{1}$ & $7,85^{2}$ & $11,99^{1}$ & 0,19 & 63,11 \\
\hline 5 & $\mathrm{R} 2$ & $32,83^{1}$ & $8,22^{2}$ & $10,49^{1}$ & 0,33 & 31,79 \\
\hline 0 & R3 & $22,92^{1,2}$ & $7,69^{2}$ & $12,92^{1}$ & 0,16 & 80,75 \\
\hline 1 & R3 & $26,31^{1}$ & $7,71^{2}$ & $9,97^{1}$ & 0,21 & 47,48 \\
\hline 2 & R3 & $31,27^{1}$ & $7,61^{2}$ & $10,36^{1}$ & 0,13 & 79,69 \\
\hline 3 & $\mathrm{R} 3$ & $36,60^{1}$ & $7,37^{1,2}$ & $17,55^{1,2}$ & 0,24 & 73,13 \\
\hline 4 & R3 & $35,57^{1}$ & $7,69^{2}$ & $12,68^{1}$ & 0,23 & 55,13 \\
\hline 5 & R3 & $33,72^{1}$ & $8,10^{2}$ & $10,91^{1}$ & 0,18 & 60,61 \\
\hline 0 & $\mathrm{R} 4$ & $28,78^{1}$ & $7,59^{2}$ & $15,63^{1,2}$ & 0,15 & 104,20 \\
\hline 1 & $\mathrm{R} 4$ & $31,25^{1}$ & $7,56^{2}$ & 7,61 & 0,26 & 29,27 \\
\hline 2 & $\mathrm{R} 4$ & $34,44^{1}$ & $7,47^{1,2}$ & $12,06^{1}$ & 0,20 & 60,30 \\
\hline 3 & $\mathrm{R} 4$ & $42,02^{1}$ & $7,59^{2}$ & $19,19^{1,2}$ & 0,33 & 58,15 \\
\hline 4 & $\mathrm{R} 4$ & $39,66^{1}$ & $7,51^{2}$ & $12,86^{1}$ & 0,21 & 61,24 \\
\hline 5 & $\mathrm{R} 4$ & $40,31^{1}$ & $7,63^{2}$ & $10,90^{1}$ & 0,30 & 36,33 \\
\hline 0 & R5 & $31,81^{1}$ & $7,62^{2}$ & $19,21^{1,2}$ & 0,24 & 80,04 \\
\hline 1 & R5 & $31,54^{1}$ & $7,83^{2}$ & $19,88^{1,2}$ & 0,28 & 71,00 \\
\hline 2 & R5 & $40,75^{1}$ & $7,74^{2}$ & $19,03^{1,2}$ & 0,36 & 52,86 \\
\hline 3 & R5 & $45,22^{1}$ & $7,98^{2}$ & $16,61^{1,2}$ & $0,41^{1}$ & 40,51 \\
\hline 4 & R5 & $39,18^{1}$ & $7,97^{2}$ & $14,43^{1}$ & 0,28 & 51,54 \\
\hline 5 & R5 & $43,33^{1}$ & $7,93^{2}$ & $13,78^{1}$ & 0,31 & 44,45 \\
\hline 0 & R6 & 57,52 & $6,67^{1,2}$ & $17,17^{1,2}$ & 0,24 & 71,54 \\
\hline 1 & R6 & $43,46^{1}$ & $7,21^{1,2}$ & $12,53^{1}$ & 0,26 & 48,19 \\
\hline 2 & R6 & $47,62^{1}$ & $7,22^{1,2}$ & $13,53^{1}$ & 0,21 & 64,43 \\
\hline 3 & R6 & $44,91^{1}$ & $7,65^{2}$ & $11,40^{1}$ & 0,25 & 45,60 \\
\hline 4 & R6 & $36,73^{1}$ & $7,55^{2}$ & $13,03^{1}$ & 0,24 & 54,29 \\
\hline 5 & R6 & $47,73^{1}$ & $7,53^{2}$ & $15,89^{1,2}$ & $0,44^{1}$ & 36,11 \\
\hline \multicolumn{2}{|c|}{ SNI 19-7030-2004 } & $\leq 50$ & $\begin{array}{c}6,80- \\
7,49 \\
\end{array}$ & $9,80-32$ & $\geq 0,40$ & $10-20$ \\
\hline \multicolumn{2}{|c|}{$\begin{array}{c}\text { Permentan No } 70 \\
\text { Th } 2011\end{array}$} & $15-25$ & $4-9$ & $\geq 15$ & $\geq 4$ & $5-25$ \\
\hline
\end{tabular}


Keterangan:

${ }^{1}$ Sesuai dengan SNI 19-7030-2004

${ }^{2}$ Sesuai dengan Permentan No.70 Tahun 2011

\subsubsection{Analisis Kandungan Karbon (C-Organik)}

Kandungan C-Organik merupakan unsur penting bagi pupuk organik, karena ditujukan untuk menambah bahan organik tanah (Kusumawati, 2015). Berdasarkan SNI 19-7030-2004 kompos dikatakan baik jika memiliki kandungan C-Organik 9,80-32\%, sedangkan berdasarkan Permentan No. 70 tahun 2011 kompos dikatakan baik jika memiliki kandungan C-Organik $\geq 15 \%$. Hasil pengukuran C-Organik selama proses composting disajikan pada Gambar 3.

Berdasarkan penelitian Barakwan (2017), selama proses composting semua reaktor akan mengalami penurunan. Hal ini terjadi karena selama proses composting kandungan karbon yang terdapat dalam bahan organik akan digunakan bakteri sebagai sumber energi untuk melakukan proses metabolisme. Bakteri akan terus menerus menggunakan karbon sebagai sumber energinya sehingga jumlah karbon yang terkandung dalam bahan composting akan terus berkurang (Barakwan, 2017). R-5 mengalami penurunan yang cukup konstan dibandingkan reaktor yang lain. Hal ini menandakan bahwa kompos dengan komposisi 50\% lumpur WWTP + 50\% sampah organik merupakan kondisi terbaik bagi mikroorganisme untuk melakukan dekomposisi bahan composting. Hasil ini sejalan dengan penelitian Barakwan (2017), pada reaktor uji dengan penambahan sampah kebun pada tanah tercemar penurunan C-Organik lebih cepat dan efisiensinya besar karena C-organik pada sampah kebun kadarnya paling tinggi di bandingkan bahan composting yang lain. Tingginya kadar COrganik pada sampah kebun sebagai nutrisi tambahan untuk sumber energi mikroorganisme menyebabkan aktivitas, pertumbuhan, dan jumlah mikroorganisme berjalan semakin cepat dan banyak. Oleh karena itu, C-Organik semakin cepat menurun kadarnya karena besarnya jumlah mikroorganisme yang mengkonsumsi (Barakwan, 2017).

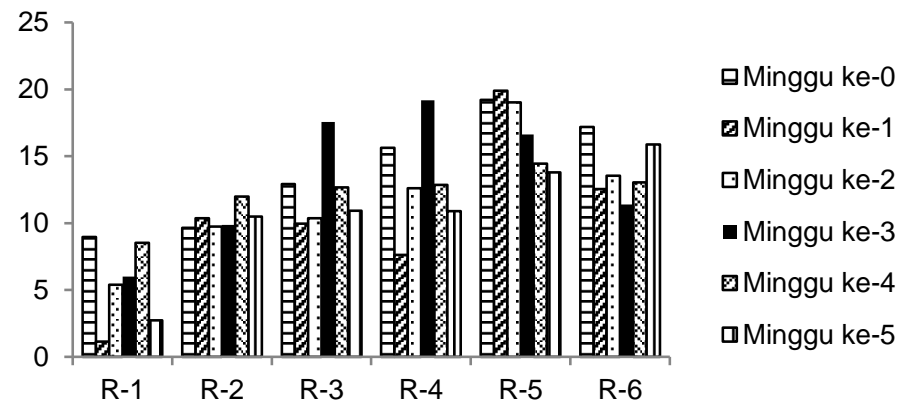

Gambar 3. Hasil Pengujian Kandungan Karbon (C-Organik)

\subsubsection{Analisis Kandungan Nitrogen (N-Total)}

Nitrogen adalah unsur utama dalam penyediaan nutrisi tanaman, dan merupakan komponen utama dalam klorofil, protoplasma dan protein (Budiyanto, 2015). Berdasarkan SNI 19-7030-2004 kompos dikatakan baik jika memiliki kandungan $\mathrm{N}$-Total $\geq 0,40 \%$, sedangkan berdasarkan Permentan No. 70 tahun 2011 kompos dikatakan baik jika memiliki kandungan N-Total $\geq 4,0 \%$. Hasil pengukuran N-Total selama proses composting disajikan pada Gambar 4. 


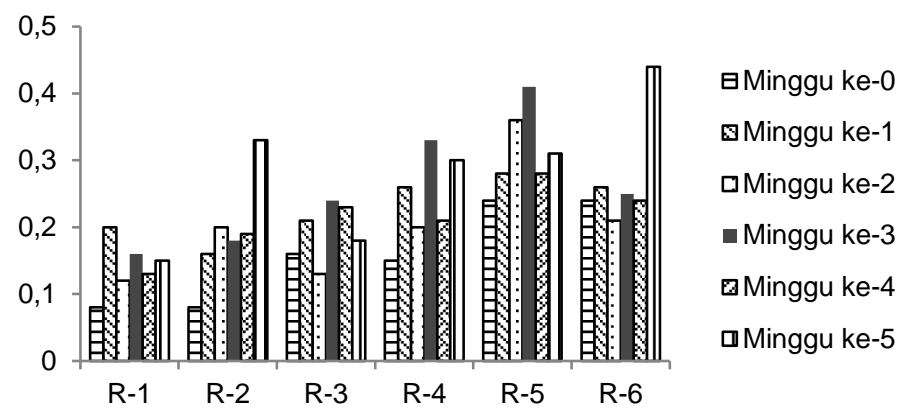

Gambar 4. Hasil Pengukuran N-Total selama Proses Composting

Pada awal composting (minggu ke-0), kadar N-Total pada reaktor uji berkisar antara 0,08-0,24\%. Kandungan N-Total terbesar dimiliki oleh R-5 dan R-6 yaitu 0,24\%, sedangkan kandungan N-Total terkecil dimiliki oleh R-1 dan R-2 yaitu 0,08\%. Pada semua reaktor uji, kandungan N-Total selama proses composting bersifat fluktuatif. Peningkatan kandungan N-Total disebabkan adanya dekomposisi bahan organik tanah, pengikatan oleh mikroorganisme, dan penambahan bahan organik yang mengandung N-Total tinggi. Mekanisme dekomposisi bahan organik menjadi nitrogen dalam tanah adalah melalui proses aminasi, amonifikasi dan nitrifikasi. Aminasi adalah pembentukkan asam amino dari bahan organik (protein) oleh bermacam-macam (heterogeneous) mikroorganisme. Amonifikasi adalah pembentukkan ammonium dari senyawa-senyawa amino oleh mikroorganisme. Nitrifikasi adalah perubahan dari ammonium $\left(\mathrm{NH}_{4}^{+}\right)$menjadi nitrit oleh bakteri Nitrosomonas kemudian menjadi nitrat oleh bakteri Nitrobacter. Sedangkan penurunan kandungan N-Total disebabkan adanya kehilangan nitrogen dalam bentuk amoniak yang sangat mudah menguap ke udara sehingga kadar nirogen menurun sementara terjadi proses nitrifikasi (Barakwan, 2017). Reaktor yang memiliki grafik relatif konstan adalah R-5. Kandungan N-Total pada R-5 mengalami peningkatan hingga minggu ke-3, tetapi mengalami penurunan pada minggu ke-4, dan meningkat lagi pada minggu ke-5.

\subsubsection{Analisis Rasio $\mathrm{C} / \mathrm{N}$}

Rasio C/N merupakan perbandingan kadar karbon (C) dan kadar nitrogen (N) dalam suatu bahan (Hayati, 2015). Rasio C/N yang terkandung di dalam kompos menggambarkan tingkat kematangan dari kompos (Kusumawati, 2015). Selama proses composting, rasio C/N secara bertahap menurun. Hal ini terjadi karena setiap kali senyawa organik yang dikonsumsi oleh mikroorganisme, dua pertiga dari karbon hilang ke atmosfir sebagai gas $\mathrm{CO}_{2}$, sementara sebagian besar nitrogen di daur ulang ke dalam mikroorganisme baru (Anindita, 2012). Grafik hasil pengukuran rasio C/N disajikan pada Gambar 5.

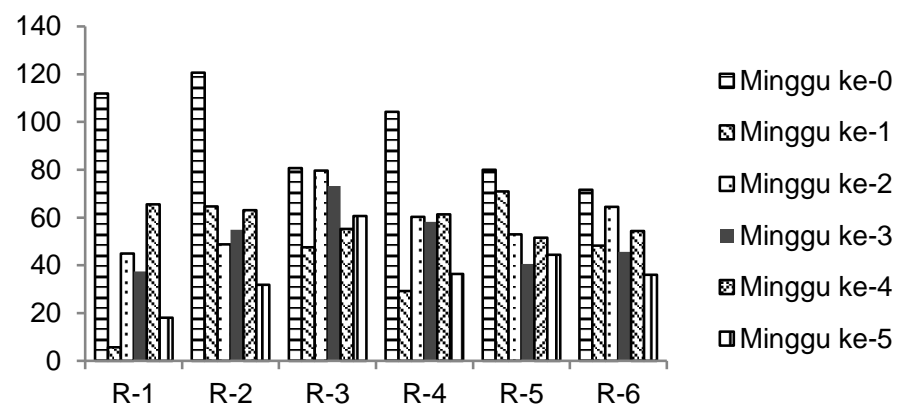

Gambar 4.5. Grafik Hasil Pengukuran Rasio C/N 
Pada awal proses composting (minggu ke-0), rasio $\mathrm{C} / \mathrm{N}$ berkisar antara 120,63-71,54\%. Rasio $\mathrm{C} / \mathrm{N}$ terbesar dimiliki oleh R-2 yaitu 120,63\%, dan reaktor dengan rasio C/N terkecil adalah R-6 yaitu $71,54 \%$. Nilai rasio $\mathrm{C} / \mathrm{N}$ ini tergolong tinggi. Rasio $\mathrm{C} / \mathrm{N}$ yang efektif untuk proses composting berkisar antara 30:1 hingga 40:1, karena pada kondisi ini mikroorganisme mendapat cukup karbon untuk energi dan $\mathrm{N}$ untuk sintesis. Rasio $\mathrm{C} / \mathrm{N}$ yang lebih tinggi dari angka 40:1 ini tidak menyediakan nitrogen yang cukup untuk pertumbuhan optimal populasi mikroorganisme, yang mengakibatkan kompos relatif tetap dingin dan terdegradasi secara lambat (Anindita, 2012). Hal ini disebabkan karena bahan yang mengandung nitrogen terlalu sedikit tidak mampu menghasilkan panas yang cukup untuk membusukkan bahan baku kompos dengan cepat (Haug, 1989, dalam Wicaksosno, 2012).

Tingginya rasio $\mathrm{C} / \mathrm{N}$ diawal penelitian diakibatkan adanya perbedaan lumpur WWTP dan abu bioler yang diambil untuk uji pendahuluan. Hasil perbandingan karakteristik bahan composting sebelum dan setelah proses pembuatan biodiesel berjalan disajikan pada Tabel 3. Saat pengambilan lumpur untuk penelitian utama proses produksi biodiesel yang dilakukan oleh PT Smart Tbk telah berjalan. Hal ini menyebabkan adanya peningkatan bahan organik yang terkandung di dalam lumpur WWTP. Berdasarkan Tabel 3 diketahui bahwa ada peningkatan karbon yang relatif tinggi dan penurunan nitrogen. Hal ini menyebabkan rasio C/N pada lumpur WWTP sangat tinggi, yaitu 268,82.

Penurunan rasio $\mathrm{C} / \mathrm{N}$ dari awal proses composting hingga akhir composting membuktikan bahwa lumpur WWTP dan abu boiler terbukti dapat digunakan sebagai bahan composting. Berdasarkan Gambar 8, terdapat satu reaktor yang memiliki grafik penurunan rasio $\mathrm{C} / \mathrm{N}$ relatif konstan, yaitu $\mathrm{R}-$ 5. Pada $\mathrm{R}-5$ rasio $\mathrm{C} / \mathrm{N}$ dari minggu ke-0 menurun konstan hingga minggu ke-3. Penurunan rasio $\mathrm{C} / \mathrm{N}$ disebabkan menurunnya kandungan $\mathrm{C}$-Organik dan meningkatnya kandungan $\mathrm{N}$-Total pada bahan composting. Pada minggu ke-4 terjadi peningkatan rasio $\mathrm{C} / \mathrm{N}$ dan menurun lagi pada minggu ke-5. Adanya peningkatan ini disebabkan oleh jumlah $\mathrm{C}$-organik yang terlalu tinggi sementara jumlah N-total yang sangat kecil karena sebagian besar N-total hilang akibat menguapnya amonia sehingga kebutuhan $\mathrm{N}$-total untuk perkembangan dan aktivitas mikroorganisme sangat kurang yang menyebabkan mikroorganisme lambat dalam mendekomposisi bahan organik (Barakwan, 2017).

Tabel 3. Perbandingan Karakteristik Bahan Composting Sebelum dan Setelah Proses Pembuatan Biodiesel Berjalan

\begin{tabular}{|c|c|c|c|c|c|c|c|}
\hline \multirow{2}{*}{ No. } & \multirow{2}{*}{ Bahan } & \multicolumn{2}{|c|}{ C-Organik } & \multicolumn{2}{|c|}{ N-Total } & \multicolumn{2}{|c|}{ Rasio C/N } \\
\hline & & Sebelum & Setelah & Sebelum & Setelah & Sebelum & Setelah \\
\hline 1. & $\begin{array}{l}\text { Lumpur } \\
\text { WWTP }\end{array}$ & 1,57 & 21,45 & 0,28 & 0,20 & 5,52 & 106,28 \\
\hline 2. & Abu Boiler & 0,23 & 0,26 & 0,13 & 0,07 & 1,73 & 3,75 \\
\hline
\end{tabular}

\subsubsection{Komposisi Composting dengan Kualitas Kompos Terbaik}

Komposisi composting dengan kualitas kompos terbaik jika dilihat berdasarkan kesesuaiannya dengan SNI 19-7030-2004 dan Permentan Nomor 70 Tahun 2011, komposisi composting terbaik adalah R-5 pada minggu ke-3 dengan C-Organik yaitu 16,61 (sesuai dengan SNI 19-7030-2004 dan Permenan Nomor 70 Tahun 2011) dan N-Total yaitu 0,41\% (sesuai dengan SNI 19-7030-2004), dan R-6 pada minggu ke-5 dengan C-Organik yaitu 15,89 (sesuai dengan SNI 19-7030-2004 dan Permenan Nomor 70 Tahun 2011) dan N-Total yaitu 0,44\% (sesuai dengan SNI 19-7030-2004). Kedua reaktor ini memiliki rasio C/N yang tinggi dan masih tidak sesuai dengan SNI 19-7030-2004 
dan Permenan Nomor 70 Tahun 2011, yaitu berturut-turut 40,51 dan 36,11. Tingginya rasio C/N pada kedua reaktor disebabkan karena rasio $\mathrm{C} / \mathrm{N}$ awal composting yang sangat tinggi. Akan tetapi jika dilihat penurunan rasio $\mathrm{C} / \mathrm{N}$ awal, R-5 pada minggu ke-3 memiliki penurunan yang lebih besar dibandingkan R-6 pada minggu ke-5. R-5 memiliki penurunan rasio C/N sebesar 50,61\%, sedangkan R-6 memiliki penurunan rasio $\mathrm{C} / \mathrm{N}$ sebesar 50,47\%.

Jika dilihat dari penampakan kompos (Gambar 2, halaman 4), R-5 memiliki warna kehitaman dan ukuran partikel yang lebih kecil dibandingkan reaktor lainnya, dan hasil ini sesuai dengan SNI 197030-2004 bahwa kompos yang baik adalah kompos yang memilliki warna kehitaman dan ukuran partikel antara 0,55-25 mm. Selain itu, jika dilihat dari kondisi selama composting, R-5 memiliki penurunan C-Organik (Gambar 3, halaman 6) dan rasio C/N (Gambar 5, halaman 7) yang relatif konstan, dan peningkatan N-Total yang relatif konstan (Gambar 4, halaman 6). Sehingga dapat disimpulkan bahwa komposisi bahan composting terbaik dimiliki oleh R-5, yaitu 50\% lumpur WWTP + 50\% sampah organik.

\subsection{Pengaruh Komposisi Bahan Composting terhadap Kualitas Kompos}

Data hasil pengujian kandungan $\mathrm{C}$-Organik, N-Total dan rasio $\mathrm{C} / \mathrm{N}$ selama proses composting dianalisis secara statistik menggunakan one-way ANOVA. Agar dapat dianalisis one-way ANOVA data harus lulus uji normalitas dan uji homogenitas. Hasil uji normalitas dari data pengujian kandungan C-Organik dengan tingkat signifikansi 5\% didapatkan kesimpulan bahwa semua reaktor memiliki data berdistribusi normal ( $\mathrm{p}>0,05$ ), artinya sampel penelitian yang dianalisis memiliki sebaran merata dan dapat mewakili data penelitian secara keseluruhan. Hasil uji homogenitas dengan tingkat signifikansi 5\% didapatkan kesimpulan bahwa semua data memiliki varian yang sama, artinya sampel penelitian yang dianalisis memiliki karakteristik yang sama (Sig.= $0,202, p$ > 0,05), sehingga data dapat dilanjutkan ke analisis ragam (one-way ANOVA). Hasil analisis ragam (one-way ANOVA) kandungan C-Organik semua reaktor berbeda nyata (Sig. $=0,000, p<0,05$ ). Adanya perbedaan nyata pada kandungan C-Organik menyebabkan data membutuhkan uji lanjutan. Uji lanjutan yang digunakan adalah uji lanjutan jarak berganda Duncan (DMRT) pada taraf 5\%, yang disajikan pada Tabel 4. Berdasarkan hasil analisis uji lanjutan menggunakan DMRT pada taraf 5\% pada Tabel 4 dapat diketahui bahwa R-1 berbeda nyata dari reaktor-reaktor lainnya. R-2 berbeda nyata dengan R-1, R-5, dan R-6, tetapi memiliki potensi yang sama dengan R-3 dan R-4. R-5 berbeda nyata dengan R-1, R-2, R-3, dan R-4, tetapi memiliki potensi yang sama dengan R-6. R-6 berbeda nyata dengan R-1 dan R-2, tetapi memiliki potensi yang sama dengan R-3, R-4, dan R5. Dari keenam reaktor ini dapat diketahui bahwa komposisi R-1, R-2, dan R-5 merupakan komposisi yang menghasilkan kandungan C-Organik berbeda nyata. Sedangkan reaktor dengan nilai rata-rata kandungan C-Organik tertinggi dan sesuai dengan SNI 19-7030-2004 serta Permentan Nomor 70 Tahun 2011 adalah R-5, yaitu 17,157.

Data hasil analisis kandungan N-Total secara statistik menggunakan one-way ANOVA adalah sebagai berikut: Hasil uji normalitas dari data pengujian kandungan N-Total dengan tingkat signifikansi 5\% didapatkan kesimpulan bahwa semua reaktor memiliki data berdistribusi normal ( $\mathrm{p}$ $>0,05)$, artinya sampel penelitian yang dianalisis memiliki sebaran merata dan dapat mewakili data penelitian secara keseluruhan. Hasil uji homogenitas dengan tingkat signifikansi 5\% didapatkan kesimpulan bahwa semua data memiliki varian yang sama, artinya sampel penelitian yang dianalisis memiliki karakteristik yang sama (Sig. $=0,808, \mathrm{p}>0,05$ ), sehingga data dapat dilanjutkan ke analisis ragam (one-way ANOVA). Hasil analisis ragam (one-way ANOVA) kandungan N-Total semua reaktor berbeda nyata (Sig. $=0,003, \mathrm{p}<0,05$ ). Adanya perbedaan nyata pada kandungan $\mathrm{N}-$ Total menyebabkan data membutuhkan uji lanjutan. Uji lanjutan yang digunakan adalah uji lanjutan 
jarak berganda Duncan (DMRT) pada taraf 5\%, yang disajikan pada Tabel 4. Berdasarkan hasil analisis uji lanjutan menggunakan DMRT pada taraf 5\% pada Tabel 4 dapat diketahui bahwa R-1 berbeda nyata dengan R-4, R-5, dan R-6, tetapi memiliki potensi yang sama dengan R-2 dan R-3. R-2 dan R-3 berbeda nyata dengan R-5, tetapi memiliki potensi yang sama dengan R-1, R-4, dan R6. R-4 berbeda nyata dengan R-1, tetapi memiliki potensi yang sama dengan R-2, R-3, R-5, dan R6. R-5 berbeda nyata dengan R-1, R-2, dan R-3, tetapi memiliki potensi yang sama dengan R-4 dan R-6. R-6 berbeda nyata dengan R-1, tetapi memiliki potensi yang sama dengan R-2, R-3, R-4, dan R-5. Dari keenam reaktor ini dapat diketahui bahwa komposisi R-1 dan R-5 merupakan komposisi yang menghasilkan kandungan N-Total berbeda nyata. Sedangkan reaktor dengan nilai rata-rata kandungan N-Total tertinggi adalah R-5, yaitu 0,313.

Tabel 4. Hasil Uji Lanjutan DMRT 5\% Kandungan C-Organik dan N-Total

\begin{tabular}{ccc}
\hline Kode Reaktor & C-Organik & N-Total \\
\hline R-1 & $5.453^{\mathrm{a}}$ & $0.140^{\mathrm{a}}$ \\
R-2 & $10.350^{\mathrm{b}}$ & $0.190^{\mathrm{ab}}$ \\
R-3 & $12.398^{\mathrm{bc}}$ & $0.192^{\mathrm{ab}}$ \\
R-4 & $13.042^{\mathrm{bc}}$ & $0.242^{\mathrm{bc}}$ \\
R-5 & $17.157^{\mathrm{d}}$ & $0.313^{\mathrm{c}}$ \\
R-6 & $13.925^{\mathrm{cd}}$ & $0.255^{\mathrm{bc}}$ \\
\hline
\end{tabular}

Keterangan:

Angka yang diikuti oleh huruf yang sama pada kolom berarti tidak berbeda nyata menurut DMRT pada taraf 5\%

Data hasil analisis kandungan rasio $\mathrm{C} / \mathrm{N}$ secara statistik menggunakan one-way ANOVA adalah sebagai berikut: Hasil uji normalitas dari data pengujian rasio $\mathrm{C} / \mathrm{N}$ dengan tingkat signifikansi 5\% didapatkan kesimpulan bahwa semua reaktor memiliki data berdistribusi normal ( $p>0,05)$, artinya sampel penelitian yang dianalisis memiliki sebaran merata dan dapat mewakili data penelitian secara keseluruhan. Hasil uji homogenitas dengan tingkat signifikansi 5\% didapatkan kesimpulan bahwa semua data memiliki varian yang sama, artinya sampel penelitian yang dianalisis memiliki karakteristik yang sama (Sig. $=0,527, \mathrm{p}>0,05$ ), sehingga data dapat dilanjutkan ke analisis ragam (one-way ANOVA). Hasil analisis ragam (one-way ANOVA) rasio $\mathrm{C} / \mathrm{N}$ semua reaktor tidak berbeda nyata (Sig. $=0,834, \mathrm{p}>0,05$ ), artinya variasi komposisi bahan composting yang dilakukan tidak berpengaruh nyata dalam perubahan rasio $\mathrm{C} / \mathrm{N}$.

Analisis pengaruh komposisi bahan composting terhadap kualitas kompos ini bertujuan untuk menentukan kondisi optimum composting. Sehingga dapat disimpulkan bahwa kondisi optimum composting dengan kualitas kompos terbaik adalah R-5, dengan C-Organik yaitu 17,157\% dan NTotal yaitu $0,313 \%$.

\subsection{Analisis Perbandingan Efisiensi Biaya Pengelolaan Lumpur WWTP dan Abu Boiler dengan In Vessel Composting dan dengan Menggunakan Pihak Ketiga}

Efisiensi biaya pengelolaan lumpur WWTP dan abu boiler dianalisis secara deskriptif dengan membandingkan biaya pengelolaan lumpur WWTP dan abu boiler dengan In Vessel Composting dan biaya pengelolaan dengan menggunakan orang ketiga. Biaya dapat biaya pengelolaan lumpur WWTP dan abu boiler dengan In Vessel Composting disajikan pada Tabel 5, dan biaya pengelolaan dengan menggunakan orang ketiga disajikan pada Tabel 6. 
Tabel 5. Biaya In Vessel Composting

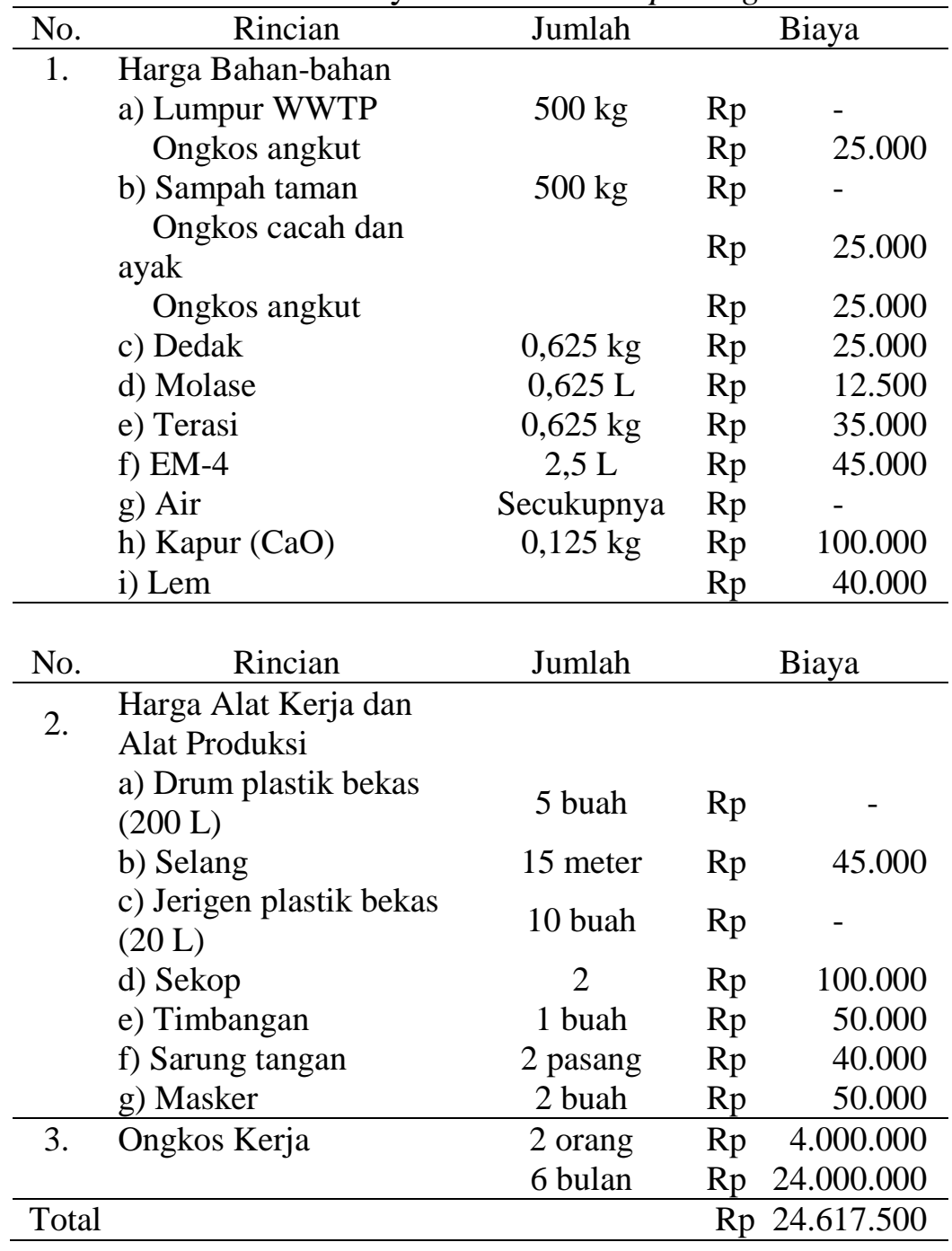

Tabel 6. Biaya Pengelolaan dengan Pihak Ketiga

\begin{tabular}{|c|c|c|c|c|}
\hline \multirow{2}{*}{$\begin{array}{c}\text { No. } \\
1 .\end{array}$} & \multirow{2}{*}{$\begin{array}{c}\text { Rincian } \\
\text { Lumpur WWTP }\end{array}$} & \multirow[t]{2}{*}{ Jumlah } & \multicolumn{2}{|r|}{ Biaya } \\
\hline & & & & \\
\hline & 1 bulan & 15 ton & $\begin{array}{c}\mathrm{Rp} \\
/ \text { ton }\end{array}$ & 150.000 \\
\hline & 6 bulan & 90 ton & $\mathrm{Rp}$ & 150.000 \\
\hline & Total & & $\mathrm{Rp}$ & 13.500 .000 \\
\hline 2 & Abu Boiler & & & \\
\hline & 1 bulan & 45 ton & $\begin{array}{l}\mathrm{Rp} \\
\text { / ton }\end{array}$ & 150.000 \\
\hline & 6 bulan & 270 ton & $\begin{array}{l}\mathrm{Rp} \\
\text { / ton }\end{array}$ & 150.000 \\
\hline & Total & & $\mathrm{Rp}$ & 40.500 .000 \\
\hline & Total Keseluru & & $\mathrm{Rp}$ & 54.000 .000 \\
\hline
\end{tabular}


Berdasarkan Tabel 5 diketahui bahwa total biaya pengelolaan lumpur WWTP dan abu boiler dengan In Vessel Composting membutuhkan biaya Rp 24.617.500,- untuk 6 bulan. Sedangkan biaya pengelolaan dengan menggunakan orang ketiga membutuhkan biaya sebesar Rp 54.000.000,- untuk 6 bulan (Tabel 6). Sehingga dapat disimpulkan bahwa pengelolaan lumpur WWTP dan abu boiler dengan In Vessel Composting memiliki efisiensi biaya pengelolaan 45,59\% lebih kecil dibandingkan menggunakan pihak ketiga.

\section{KESIMPULAN DAN SARAN}

\subsection{Kesimpulan}

Kesimpulan penelitian yang diperoleh berdasarkan hasil analisis adalah sebagai berikut:

1. Kualitas kompos yang dihasilkan dari lumpur WWTP dan abu boiler dari industri refinery dan biodiesel minyak kelapa sawit sesuai dengan SNI 19-7030-2004 dan Permentan Nomor 70 Tahun 2011, dengan kandungan C-Organik sebesar 16,61\%; kandungan N-Total sebesar $0,41 \%$; rasio C/N 40,51; dan warna kompos kehitaman.

2. Kondisi optimum composting berdasarkan komposisi bahan composting terhadap kualitas kompos adalah R-5, 50\% lumpur WWTP + 50\% sampah organik, dengan kandungan COrganik rata-rata sebesar $17,157 \%$ dan kandungan N-Total rata-rata sebesar $0,313 \%$.

3. Pengelolaan lumpur WWTP dan abu boiler dari industri refinery dan biodiesel minyak kelapa sawit dengan in vessel composting lebih efisien dibandingkan dengan menggunakan jasa pihak ketiga, dengan efisiensi sebesar $45,59 \%$.

\section{UCAPAN TERIMA KASIH}

Terima kasih kepada dosen pembimbing yaitu Dr. Andy Mizwar, ST., M.Si dan Riza Miftahul Khair, ST., M.Eng, serta kepada PT Sinar Mas Agro Resources Technology yang telah membantu pelaksanaan penelitian ini.

\section{DAFTAR PUSTAKA}

Anindita, F. 2012. Pengomposan dengan Menggunakan Metode In Vessel System untuk Sampah UPS Kota Depok. Universitas Indonesia: Depok.

Asriani, D. 2009. Analisis Kesiapan Pegawai Menerima Perubahan untuk Penerapan Balance Scorecard di Lingkungan Direktorat Jenderal Kekayaan Negara. Universitas Indonesia: Jakarta.

Astianto, A. 2013. Pemberian Berbagai Dosis Abu Boiler pada Pembibitan Kelapa Sawit (Elaeis guineensis Jacq) di Pembibbitan Utama (Main Nursery). Universitas Riau: Riau.

Badan Standarisasi Nasional. 2004. Standar Kualitas Kompos. SNI 19-7030-2004.

Budiyanto, G. 2015. Reaksi Oksido-Reduksi dalam Siklus Nitrogen. Agroteknologi Universitas Muhammadiyah Yogyakarta: Yogyakarta.

Butler, R. A. 2008. Minyak Kelapa Sawit tidak Harus Buruk Bagi Lingkungan. world.mongabay.com. Diakses pada tanggal 22 September 2016.

Cohen. 2016. Kompos. www.wikiwand.com. Diakses pada tanggal 22 September 2016.

Direktorat Jenderal Perkebunan. 2013. Pengelolaan Limbah Bahan Berbahaya dan Beracun (B3) sebagai Upaya Mendukung Perkebunan Berkelanjutan. Ditjenbun.pertanian.go.id. Diakses pada tanggal 18 Juli 2016.

Faradiba, M. E. A., dan Suwardi, S. S. 2015. Pengolahan Limbah Minyak Kelapa Sawit PT Smart Tbk Menggunakan Elekrokoagulasi Secara Kontinyu. Politeknik Negeri Malang: Malang. 
Henggar, H., dan Sugesti, S. 2009. Pemanfaatan Limbah Sludge Industri Kertas Sigaret untuk Bahan Baku Beton. Jurnal Balai Besar Pulp dan Kertas. Vol. 5. No. 34 Bandung.

Hidayati, A. A., Winardi., dan Syarifuddin. 2012. Pengomposan Sludge Hasil Pengolahan Limbah Cair PT Indofood CBP dengan Penambahan Lumpur Aktif dan EM-4 dengan Variasi Sampah Domestik dan Bawang Goreng. Universitas Diponegoro: Semarang.

Indrawati, A. 2010. Evaluasi Desain Sistem Pengolahan Limbah Cair Industri Kelapa Sawit PT Tamako Graha Krida Kec. Witaponda Kabupaten Morowali. Universitas Hasanuddin: Makassar.

Indriantoro, F. W., Said, E. G., dan Guriatno, P. 2012. Rantai Nilai Produksi Minyak Sawit Berkelanjutan. Jurnal Manajemen \& Agribisnis Volume 9 Nomor 2.

Kementerian Perdagangan. 2015. Rantai Nilai Sawit.www.inatrims.kemendag.go.id. Diakses pada tanggal 15 Juli 2016.

Lasryza, A., dan Sawitri, D. 2012. Pemanfaatan Fly Ash batubara sebagai Absorben Emisi Gas CO Kendaraan Bermotor. Jurnal Teknik Pomits Volume 1 Nomor 1.

Maceiras,R., Rodriguez, M., Cancela, A., Urrejola, S., Sanchez, A. 2011. "Macroalgae: Raw Material for Biodiesel Production”, Applied Energy, 88, hal. 3318-3323.

Mandasari, E. 2009. Pencetakan Kompos Berbagai Bentuk dengan Menggunakan Jenis Kompos yang Berbeda. Universitas Sumatera Utara: Medan.

Mizwar, A., dan Trihadiningrum, Y. 2014. Potensi Bioremediasi Tanah Terkontaminasi Polycyclic Aromatic Hydrocarbon dari Batubara dengan Composting. Prosiding Seminar Nasional Waste Management II, Institut Teknologi Sepuluh Nopember: Surabaya.

Muhammad, U. 2015. Lumpur Sawit. Ujang51.blogspot.co.id. Diakses pada tanggal 18 Juli 2016.

Nur, T., Noor, A. R., dan Elma, M. 2016. Pembuatan Pupuk Organik Cair dari Sampah Organik Rumah Tangga dengan Penambahan Bioaktivator EM-4 (Effective Microorganisms). Jurnal Konversi Volume 5 Nomor 2.

Oil World. 2014. Statistic for 17 Oil and Fats. Oil World Database Dec 2012. Oil World. Germany (DE): Oil World.

Orsolindo. 2010. Metode Pembuatan Kompos.Orsolindo.blogspot.co.id. Diakses pada tanggal 29 September 2016.

Outerbridge, T. (ed). 1991. Limbah Padat di Indonesia: Masalah atau Sumber Daya. Yayasan Obor Indonesia: Jakarta.

Priyambada, G., Yeni, E., Andesgur, I. 2015. Studi pemanfaatan Lumpur, Abu Boiler, dan Serat (Fiber) Kelapa Sawit sebagai Kompos Menggunakan Variasi Effective Microorganisme (EM-4). JOM FTEKNIK Volume 2 Nomor 2.

Putra, A., Yenie, E., dan Elystia, S. 2016. Pemanfaatan Limbah Pabrik Kelapa Sawit sebagai Kompos dengan Variasi Penambahan Dosis Abu Boiler serta Penggunaan Bioaktivator EM4. Jom Fteknik Volume 3 Nomor 1.

Rahmi, K. 2010. Aplikasi Kompos Tithonia diversifolia dan Chromolaena odorata dengan Menggunakan Dekomposer Trichoderma harzianum terhadap Ketersediaan dan Serapan Hara P oleh Tanaman Jagung pada Andisol. Universitas Sumatera Utara: Medan.

Ravina, S. 2013. Kompos: Rasio C/N. Salsabila-ravina.blogspot.co.id. Diakses pada tanggal 29 September 2016.

Redaksi Sawit Indonesia. 2014. Peluang Menjadi Raja Hilir Sawit. www.sawitindonesia.com Diakses pada tanggal 14 Juli 2016.

Risnandar, C. 2013. Jenis-jenis Pupuk Kompos. alamtani.com Diakses pada tanggal 18 Juli 2016.

Sahwan, F. L. 2010. Kualitas Produk Kompos dan Karakteristik Proses Pengomposan Ssampah Kota Tanpa Pemilahan Awal. Jurnal Teknik Lingkungan Volume 11 Nomor 1. 
Sari, G. L., Mizwar, A., dan Trihadiningrum, Y. 2015. Potensi Co-composting untuk Bioremediasi Tanah Terkontaminasi Polycyclic Aromatic Hydrocarbon (PAH). Prosiding Seminar Nasional Manajemen Teknologi XXII: Surabaya.

Sembiring, M. T., Sukardi, Suryani, A., dan Romli, M. 2015. Model Biaya Produksi Biodiesel Berbasis Minyak Sawit. Jurnal Litbang Industri Volume 5 Nomor 1.

Setyorini, D., Saraswati, R., dan Anwar, E. K. 2009. Kompos. Balai Penelitian Tanah: Bogor.

Sipayung, T. 2012. Ekonomi Agribisnis Minyak Sawit. IPB Press: Bogor.

Smart-tbk.com ${ }^{[1]}$. 2016. Our Product and Brands.www.smart-tbk.com. Diakses pada tanggal 29 September 2016.

Smart-tbk.com ${ }^{[2]}$. 2016. Pemegang Saham PT SMART Tbk Sahkan Laporan Tahunan Direksi Tahun 2015. www.smart-tbk.com. Diakses pada tanggal 19 Mei 2017.

Sugiono, A. 2006. Peluang Pemanfaatan Biodiesel dari Kelapa Sawit sebagai Bahan Bakar Alternatif Pengganti Minyak Solar di Indonesia. Pusat Pengkajian dan Penerapan Teknologi Konversi dan Konversi Energi, BPPT: Jakarta.

Sutanto, R. 2002. Penerapan Pertanian Organik. Kanisius: Yogyakarta.

Suwahyono, U. 2014. Cara Cepat Buat Kompos dari Limbah. Jakarta: Penebar Swadaya.

Syahwan, F. L. 2010. Potensi Limbah dan Karakteristik Proses Pengomposan Tandan Kosong Kelapa Sawit yang Ditambahkan Sludge Limbah Pabrik Minyak Kelapa Sawit. Jurnal Teknik Lingkungan Volume 11 Nomor 3.

Tim EHFS PT SMART Tbk. 2016. Laporan Triwulan Pengelolaan Limbah B3. PT SMART Tbk Tarjun: Kotabaru.

Tyasning, D. M., dan Masykuri, M. 2012. Pengaruh Penambahan Kitosan terhadap Biodegradasi Plastik Berbahan Polipropilen. Seminar Nasional FKIP Universitas Negeri Semarang: Semarang.

Yang, S. S. 1996. Preparation and Characterization of Compost. In Proceedings of International Training Workshop on Microbial Fertilizers and Composting. October 15-22, 1996. Taiwan Agricultural Research Institute Taichung, Taiwan, Republic of China. FFTC and TARI.

WWTP Officer. 2016. Standar Operation Procedure Wastewater Treatment Plant. PT SMART Tbk Tarjun: Kotabaru. 
JTAM Teknik Lingkungan Universitas Lambung Mangkurat, Vol 1 (2) Tahun 2018

Halaman ini sengaja dikosongkan 